\title{
Hydrochemistry of Groundwater in Northeast Part of Anbar Governorate - West of Iraq
}

\author{
Hussein Ilaibi Zamil Al-Sudani
}

\author{
Received 21/12/2017, Accepted 27/12/2018, Published 11/3/2019
}

This work is licensed under a Creative Commons Attribution 4.0 International License.

\begin{abstract}
:
A groundwater quality assessment has been carried out in northeast part of Anbar governorate in western Iraq. We analyzed hydrochemical parameters such as $\mathrm{pH}$, electrical conductivity, total dissolved solids presence of ions to describe groundwater quality. The study area has the only confined aquifer within the geological formation extended in area. Values of groundwater hydrochemical parameters were ranged from (7) to (7.9) for ph, (1599) to (6800) $\mu \mathrm{mhos} / \mathrm{cm}$ for electrical conductivity (EC) and (1048) to (4446) $\mathrm{mg} / \mathrm{l}$ for total dissolved solids (TDS). The origins and types of groundwater in the area were of marine origin and $\mathrm{MgCl}_{2}$ water type while only (6) samples were of continental origin and $\mathrm{Na}_{2} \mathrm{SO}_{4}$ water type. Groundwater utilization indicated that it can't be used for drinking purposes, while few groundwater wells can be used for agricultural and (33) groundwater samples can be used for animal purposes. However, the nature of the soil in the area and the depth of the groundwater qualified water for agricultural uses in significant and wide ranges.
\end{abstract}

Key words: Distribution, Groundwater Hydrochemistry, Salinity Utilization and Variation, Western Iraq.

\section{Introduction:}

Mankind depends on clean water for many purposes. Groundwater quality is one of the important components in the development of any area. The use of water in many regions has increased due with human population growth (1). Groundwater becomes a primary and an important resource in many areas of the world, so it is important to study its quality and quantity to identify its suitability for drinking, irrigation, industrial and other usages (2). The geochemistry of groundwater data gives crucial evidence to the geologic history of rocks and indications of groundwater recharge, movement, and storage $(3,4)$. The continuation of groundwater extraction from aquifers for all purposes is contributing to groundwater depletion in many parts of world, thus understanding of groundwater chemistry contribute in determining its usefulness for domestic and agricultural purposes (5). The earlier studies that have been done in the western desert were hydrogeology of groundwater aquifers in the Western Desert-west and southwest of the

Petroleum Technology Department- University of Technology, Ministry of Higher Education and Scientific Research, Baghdad, Iraq.

E-mail: 150098@uotechnology.edu.iq
Euphrates River (6), assessment of groundwater resources in Iraq and management of their use (7), transboundary aquifers between Iraq and neighboring countries (8), hydrogeological study of Khan Al-Baghdadi area in Anbar governorate West of Iraq (9), and the influence of Structural Factors on Groundwater System - West of Iraq (10).

The evaluation of groundwater shall focus on agricultural and industrial use as well as the origin and types of groundwater in the northeast part of Anbar governorate in the western Iraq. The area covers $(6290) \mathrm{km}^{2}$ within $\left(41^{\circ} 50^{\prime}-42^{\circ} 45^{\prime}\right) \mathrm{E}$ and $\left(33^{\circ} 30^{\prime}-34^{\circ} 15^{\prime}\right)$ N. as shown in Fig.1. The work plan in the studied area included office work where data and preliminary information of the area were prepared, while field work included four major items; inventory of water wells and measuring water levels as well as determine geographical positions and other hydrogeological properties of forty seven wells using (GPS) device during (20102011), water sampling of forty nine wells within water surplus and water deficit periods during 20102011, water sampling of one well (Alus) for twelve months during 2010-2011 and finally laboratory analysis of sixty one water samples to measure physical and chemical components and variation of ionic concentrations. The chemical analysis was 


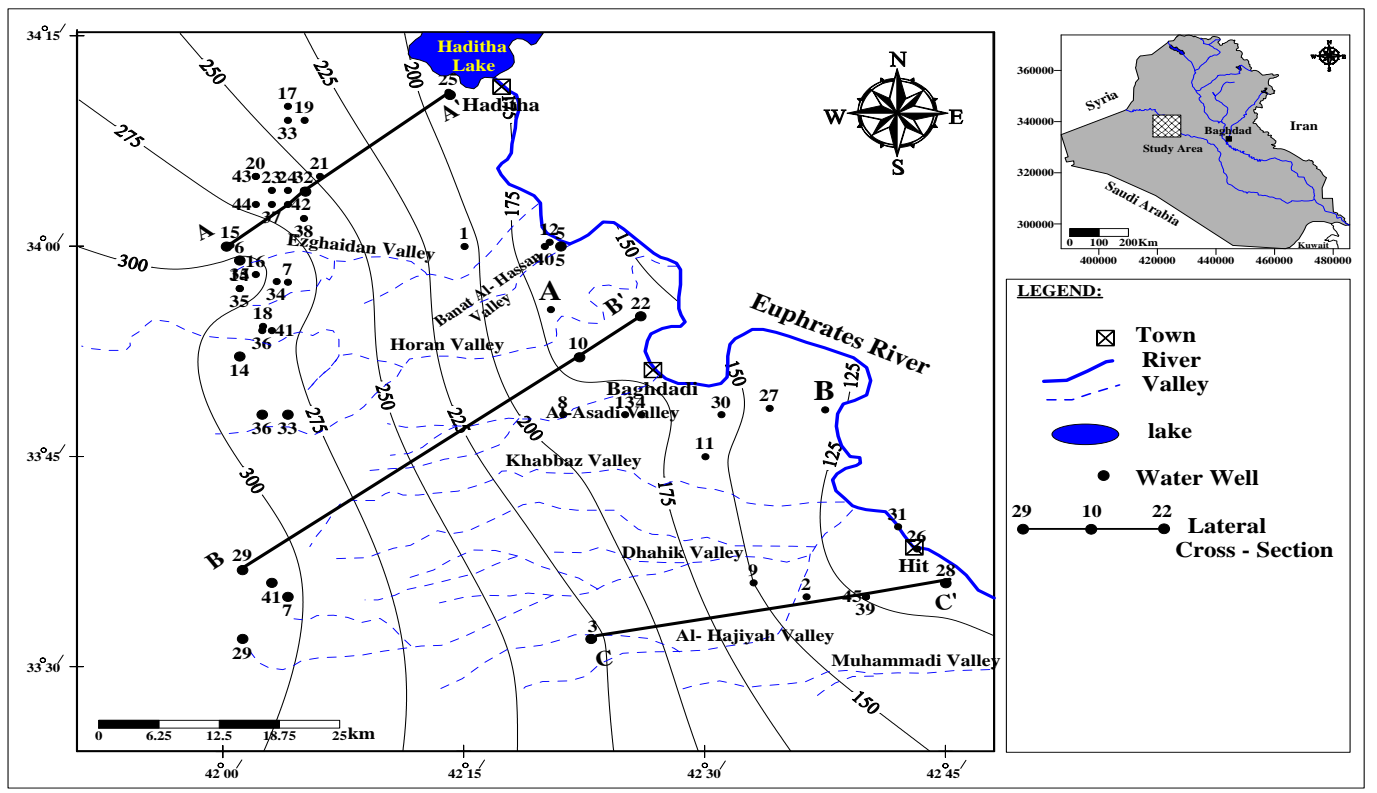

Figure 1. Topography and well locations map of Khan Al-Baghdadi area.

done in General Commission of Groundwater laboratories, Ministry of Water Resources.

The aim of this research is to evaluate groundwater aquifers quality depending on the hydrochemical properties distribution within area and time.

\section{Geological Setting:}

The area is built up of sedimentary rocks ranging in age from lower Oligocene to Pliocene, with different types of Quaternary deposits (Pleistocene-Holocene). The area lies within different structural zones from east to west. This region contains the Tigris subzone up the Mesopotamian zone of the Unstable Shelf and the Salman and Rutba-Jazira zones of the Stable Shelf (10).

\section{Stratigraphy:}

The Shurau and Sheikh Alas formation is composed of limestone recrystallized, hard to very hard and splintery. The Anah formation consists of massive, very hard limestone and dolomite limestone, locally strongly Karstified leading to cavities and caverns of different sizes. The Euphrates formation consists of thin basal conglomerate or basal clastic with recrystallizedy cherty, silicified, ferruginous and marly limestone, and greenish marl. The Fatha (Lower Fars) consists of cyclic nature (marl, limestone, gypsum and claystone). Finally the Quaternary deposits consist of medium grained, well rounded pebbles, secondary gypsum or highly gypiferous soil, sand, silt and clay with rock fragments, gravels mixed with sand and high admixture of rock fragments (11). As shown in Fig.2. 


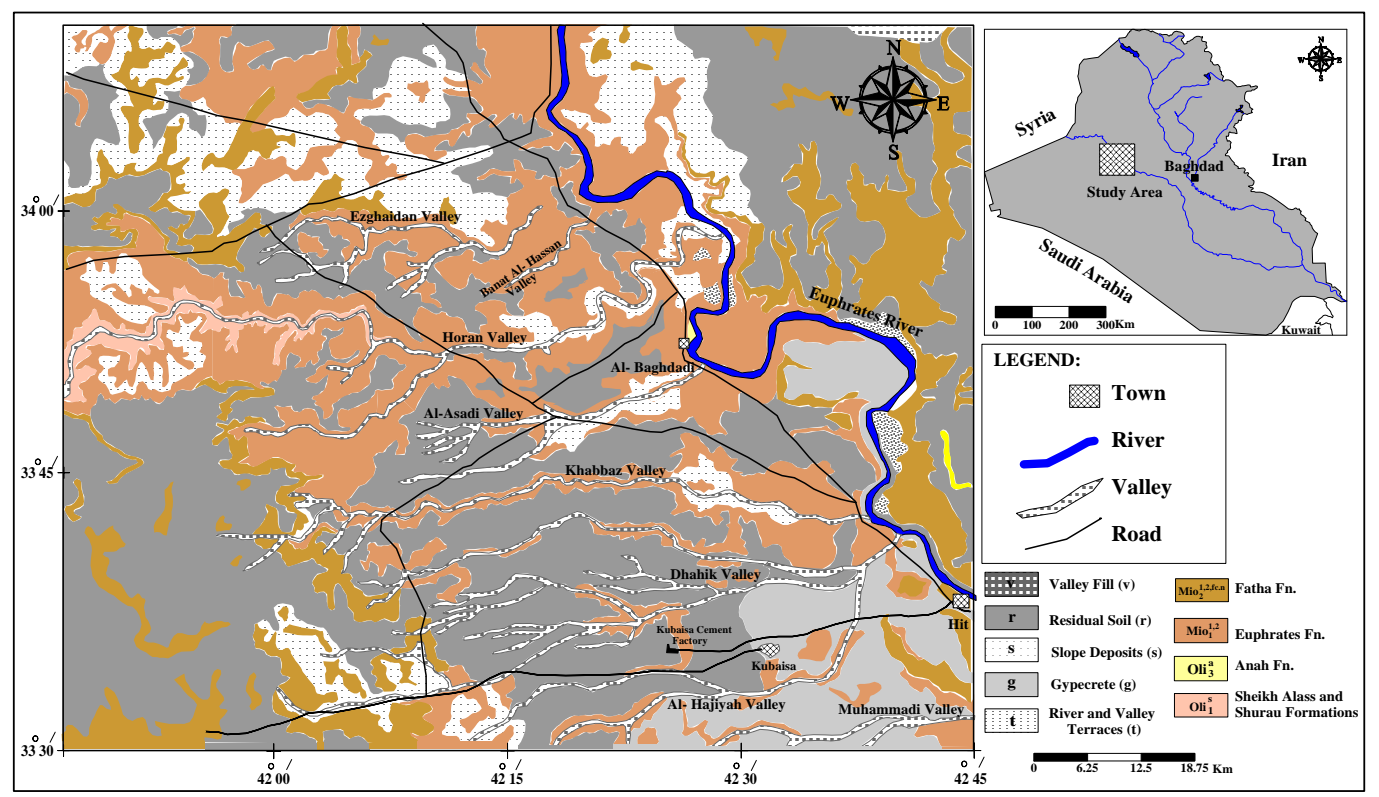

Figure 2. Geological map of Khan Al-Baghdadi Area (11).

Materials and Methods:

The materials used in this study were:

1- Topographic, geological and tectonic maps of area with different map scale.

2- GPS device to determine wells locations and elevations as well as others hydrogeological properties.

3- Stratigraphic sheets and hydrogeological data bank (12).

4- Grapher and Surfer programs demonstrating graphs and contour maps.

Taking into consideration the forty seven groundwater levels measured in wells inventoried in the area as well as types of water bearing layers, the stratigraphic sheets of these wells, which was obtained from a hydrogeological data bank had been compared with Fig.3 to determine aquifer hydrogeological and hydrochemical properties, where each aquifer has different hydrogeological and hydrochemical characteristics. The aquifer was investigated during fieldwork where geographical position, elevations, static water levels, depths, thicknesses and maximum yield had been carried out. The methodology depends on collecting forty nine water samples from groundwater wells during June, 2010 to June, 2011, with sample locations shown in Fig.1.

Physicochemical properties of water samples such as $\mathrm{pH}$, electric conductivity (EC), and major cations and anions were measured and analyzed by standard methods (13). The chemical analysis was done in General Commission of Groundwater laboratories, Ministry of Water Resources. Mathematical programs (Surfer and Grapher) were used to demonstrate the obtained results in contouring maps of hydrogeological and hydrochemical properties.

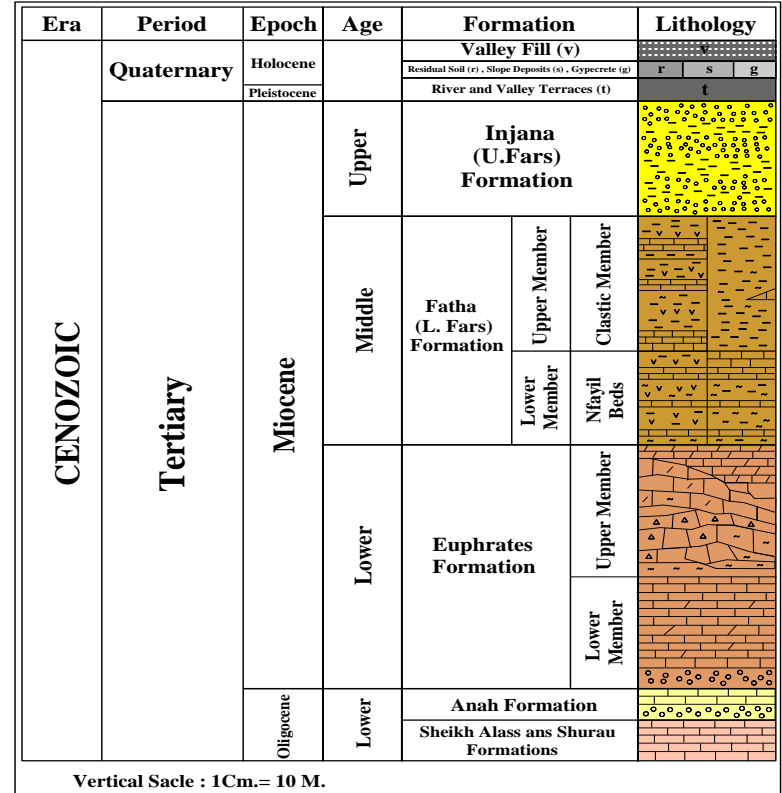

Figure 3. Stratified sequence of geological formations in the studied area (11)

\section{Results and Discussion:}

\section{Hydrogeological Properties of Aquifer:}

According to forty seven wells investigated in the area, the results showed that the area has the only confined aquifer within the geological formation extended in this area (9). It can be seen that geological water bearing formations in the western part of area consist of Tayarat, Umm Er-Radhuma and Dammam (subsurface) formations, especially in the northwestern part of the area as shown in Fig.4 sections A,B and C. The groundwater is confined in Umm Er-Radhuma and Dammam formations in the central part of the western side. The Anah and Euphrates formations become the essential geological water-bearing formations in the northeast part of the area. The most important characteristic 
of the geological formations and its aquifers in the eastern area of the Western desert and in the northern region of the Anbar governorate is hydraulic connections among sequenced geological formations where groundwater moves from deeper water-bearing layers into lesser depth through groundwater flow in the eastern direction $(6,9,10)$. This characteristic allows the aquifers to be recharge with huge quantities of groundwater. In addition these aquifers may be considered into a confined condition under higher pressure due to the overlain geological formation (14). The geological water bearing formations gradually formed by Tayarat, Umm Er-Radhuma and Dammam (subsurface) formations in the western part, the Umm Er-Radhuma and Dammam formations in the central part, and Euphrates as essential formation and Anah with Fatha as an occasional formation in the east and northeast part of the area (10). (Table 1) showed the statistical data of hydrogeological properties of aquifer in the study area.

Table 1. Statistical data shows aquifer hydrologeological properties in the area

\begin{tabular}{cccccc}
\hline Statistic & Number of samples & Minimum & Maximum & Mean & Standard deviation \\
\hline Elevation (m) & 32 & 100 & 316.9 & 217.72 & 67.781 \\
Static water level (m.) & 43 & 0 & 154.7 & 61.67 & 42.654 \\
Dynamic water level (m) & 42 & 1.5 & 155.9 & 73.324 & 39.011 \\
Piezomteric level (m.a.s.l.) & 31 & 69 & 219 & 161.97 & 36.264 \\
Total depth (m) & 47 & 45.5 & 902.6 & 152.03 & 122.07 \\
Aquifer depth (m) & 34 & 31 & 154.7 & 79.288 & 30.944 \\
Thickness (m.) & 42 & 15 & 110 & 62.11 & 26.61 \\
Maximum yield (m*3/day) & 45 & 76 & 6480 & 859 & 993.73 \\
\hline
\end{tabular}

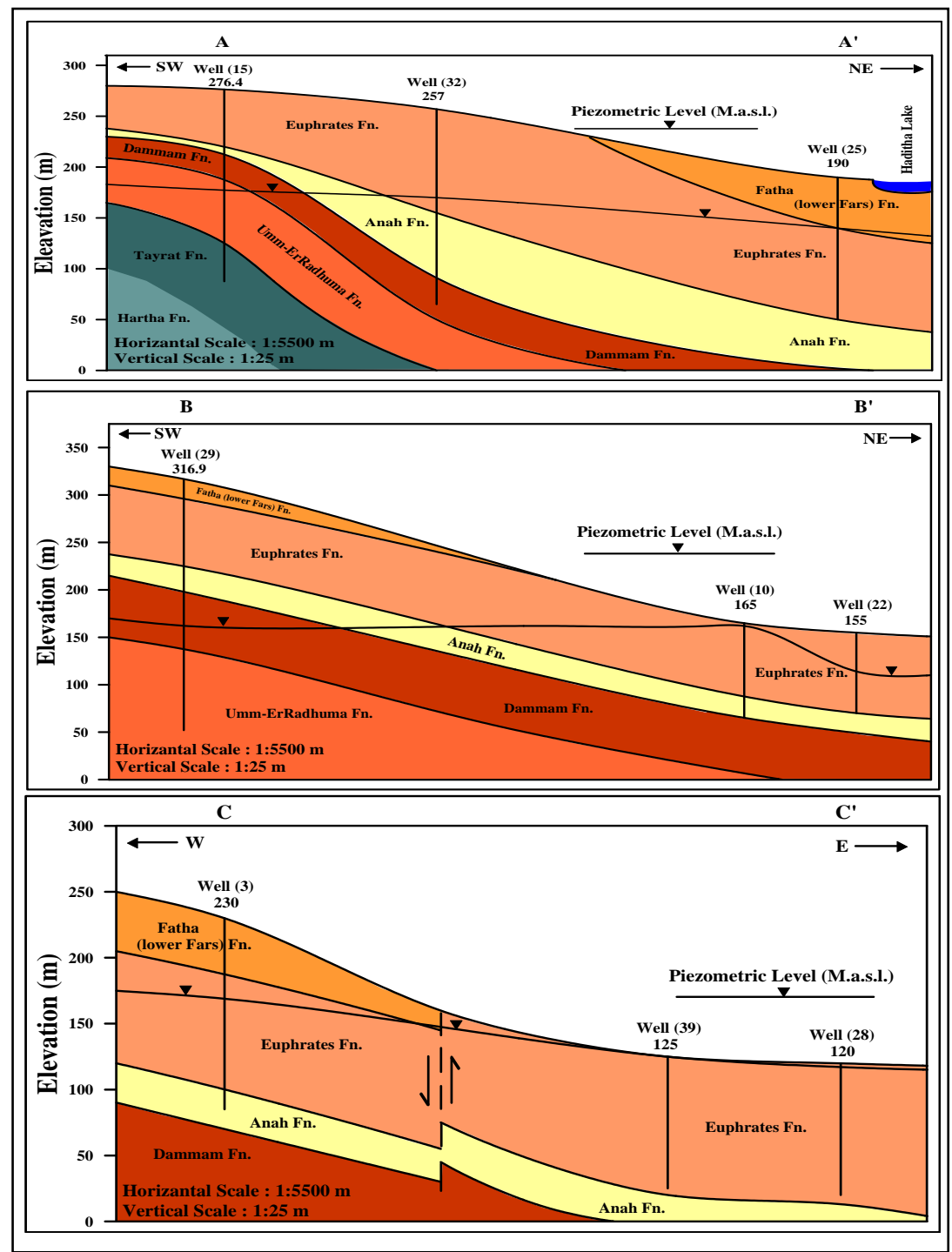

Figure 4. Lateral cross -sections in studied area showing geological water bearing formations (10) 


\section{Groundwater Chemistry:}

The statistical data of hydrochemical groundwater samples is shown in (Table 2). The ranges of $\mathrm{pH}$, electrical conductivity (EC) and total dissolved solids (TDS) represented as minimum and maximum were (7) to (7.9) and (1599) to (6800) $\mu \mathrm{mhos} / \mathrm{cm}$, (1048) to (4446) $\mathrm{mg} / \mathrm{l}$ respectively. These values indicate that groundwater is brackish to saline types where (TDS > $1000 \mathrm{mg} / \mathrm{l}$ ) (15). As mentioned before, the main geological water bearing formations in the area are Tayarat, Umm Er-Radhuma, Dammam, Euphrates, Anah and Fatha which are all of marine depositional environments. This means the groundwater's origin is marine water diluted with fresh rainwater which has infiltrated within fractures and joints, extended in the area to decrease groundwater quality in some wells.

\section{Distribution of Groundwater Salinity within area:}

Salinity, as expressed in total dissolved salts (TDS) is the most important parameter in groundwater hydrochemical studies, where salinity of the groundwater changes by location and time within the hydrogeological basin and water depth in aquifer. The salinity is the first element in determining the validity of groundwater use for different purposes. The geological and topographical conditions play an important role in changing salinity values due to effects of geological formations exposures and quality of water recharge the aquifer affected by topography of the basin (16). Depending on (Table 2), the groundwater salinity distribution within the area has been illustrated in Fig.5, where salinity increased towards east and north east part of the area to reflect a regular increasing in salinity concentrations due to groundwater flow direction under pressure. This leads to increase reaction between rocks and groundwater and increasing salinity concentrations within the direction of flow. The water-bearing layers consists of limestone and dolometic limestone of Euphrates, Anah and Fatha formations of marine depositional environment which mean that groundwater origin is marine water (9). The most important characteristic of aquifers in the area is hydraulic connections among sequenced geological formations, which is where groundwater moves from deeper water-bearing layers within fractures and faults extended in the area into lesser depth causing by gradually increasing of salinity in groundwater within distance as shown in Fig.5.

Table 2. Statistical data of the physicochemical analysis of the groundwater in the area

\begin{tabular}{|c|c|c|c|c|c|c|c|c|c|c|c|c|c|}
\hline$\underbrace{\infty}_{0}$ & $\stackrel{\mathbb{I}}{\boldsymbol{L}}$ & 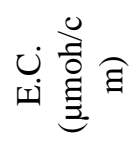 & 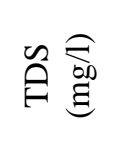 & 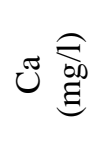 & 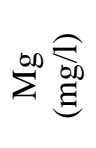 & 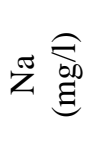 & 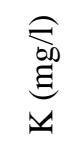 & $\begin{array}{l}\widehat{\widehat{\sigma}} \\
\stackrel{\Xi}{\Xi} \\
\bar{U}\end{array}$ & 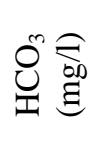 & ○े & 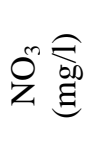 & $\begin{array}{l}\sigma^{0} \\
\tilde{Z}\end{array}$ & $\underset{\sim}{\stackrel{4}{4}}$ \\
\hline $\begin{array}{c}\text { Number of } \\
\text { samples }\end{array}$ & 49 & 49 & 49 & 49 & 49 & 49 & 49 & 49 & 49 & 49 & 49 & 49 & 49 \\
\hline Minimum & 7 & 1599 & 1048 & 125 & 74 & 160 & 2 & 300 & 25 & 518 & 0 & 21.9 & 2 \\
\hline Maximum & 7.91 & 6800 & 4446 & 402 & 235 & 585 & 75 & 1180 & 483 & 1792 & 15 & 52.7 & 7.1 \\
\hline Mean & 7.34 & 4559 & 2964.7 & 299.7 & 177 & 352 & 13.7 & 664.5 & 133.2 & 1131.8 & 2.5 & 35.4 & 4 \\
\hline $\begin{array}{l}\text { Standard } \\
\text { deviation }\end{array}$ & 0.23 & 1118 & 716.7 & 59.5 & 38.8 & 94 & 11.2 & 200.9 & 106.5 & 319.6 & 3.2 & 6.5 & 1.1 \\
\hline
\end{tabular}

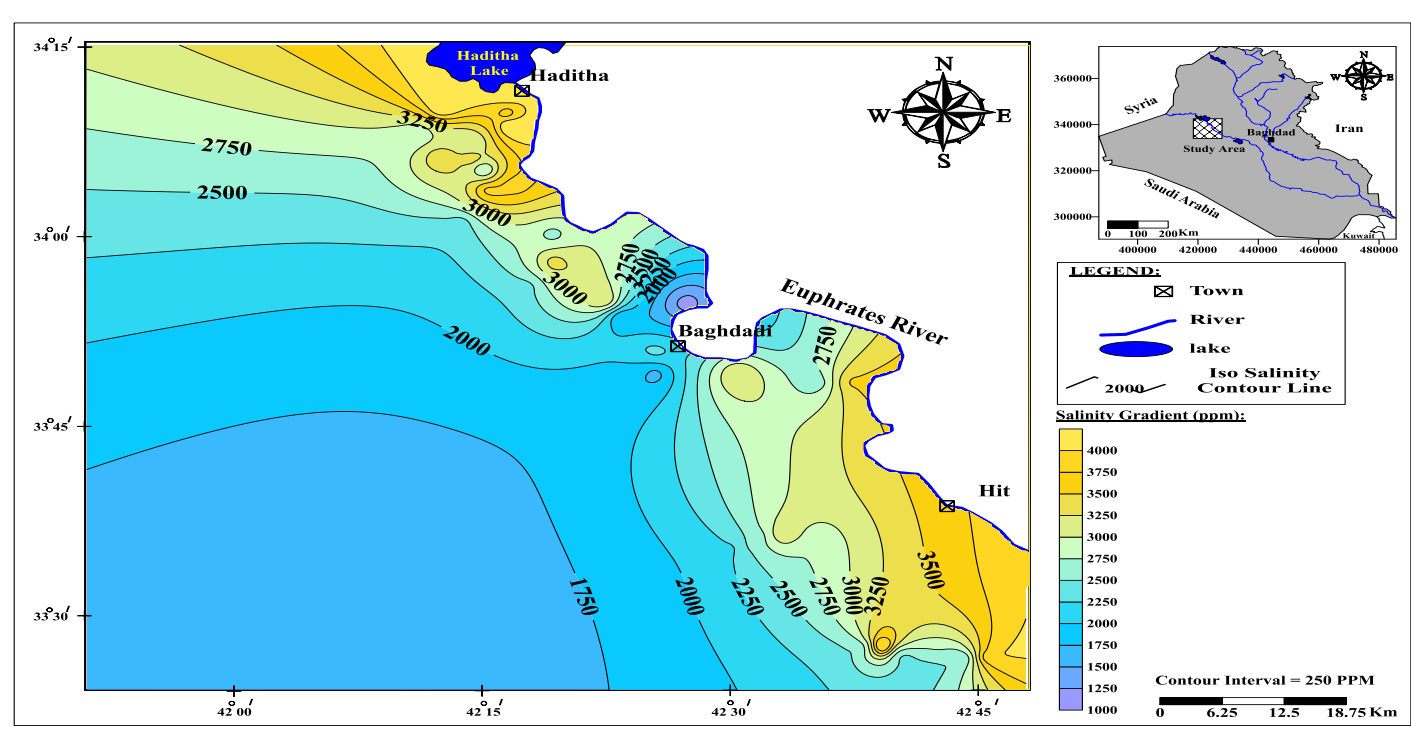

Figure 5. Groundwater salinity distribution within study area 
Variation of Groundwater Salinity within Time:

The variation in groundwater salinity shows heterogeneity of groundwater recharge at short-term monitoring periods. These changes are reflected in the salinity concentration between recharge and sub-surface discharge areas within time in the basin or when there is a local groundwater recharging activities due to rivers or lakes (17). (Table 3) shows the groundwater salinity variation within time in well (A-Alus) where groundwater sampling carried out within twelve months in (2010-2011). The salinity variation with time in this well illustrated in Fig. 6, where salinity as an indicator of ions was characterized by increasing value in water deficit period during June to September, while decreasing values recorded in water surplus period during October to March, and minimum concentration of salinity was recorded in January 2011. This well showed normal behavior of changing in salinity concentrations within time, with respect to the location of the well in the discharge area of the basin, taking into consideration the time required to recharge the aquifer with fresh water, depending on groundwater flow path. The recharge rate of groundwater reduces salinity concentrations within water surplus period due to ionic exchange between the recharge water and original groundwater in porous medium. The quality of groundwater changes due to ionic exchange between the water and porous medium which, may require a long time. Groundwater recharge, mixing of origin and recharged waters reflect another change in salinity and groundwater quality $(14,18)$.

Table 3. Groundwater salinity and ions variation within time in well (A- Alus)

\begin{tabular}{cccccccccc}
\hline Date & $\begin{array}{c}\mathrm{TDS} \\
(\mathrm{mg} / \mathrm{l})\end{array}$ & $\begin{array}{c}\mathrm{Ca} \\
(\mathrm{mg} / \mathrm{l})\end{array}$ & $\mathrm{Mg}(\mathrm{mg} / \mathrm{l})$ & $\begin{array}{c}\mathrm{Na} \\
(\mathrm{mg} / \mathrm{l})\end{array}$ & $\begin{array}{c}\mathrm{K} \\
(\mathrm{mg} / \mathrm{l})\end{array}$ & $\begin{array}{c}\mathrm{HCO}_{3} \\
(\mathrm{mg} / \mathrm{l})\end{array}$ & $\begin{array}{c}\mathrm{SO}_{4} \\
(\mathrm{mg} / \mathrm{l})\end{array}$ & $\begin{array}{c}\mathrm{CL} \\
(\mathrm{mg} / \mathrm{l})\end{array}$ & $\begin{array}{c}\mathrm{NO}_{3} \\
(\mathrm{mg} / \mathrm{l})\end{array}$ \\
\hline $20 / 6 / 2010$ & 2167 & 200 & 110 & 240 & 6 & 110 & 504 & 607 & 1.8 \\
$20 / 7 / 2010$ & 2225 & 205 & 112 & 245 & 6.5 & 114 & 512 & 620 & 1.8 \\
$20 / 8 / 2010$ & 2434 & 263 & 179 & 140 & 15 & 249 & 817 & 420 & 7.1 \\
$20 / 9 / 2010$ & 2470 & 204 & 100 & 368 & 10 & 345 & 641 & 536 & 12.1 \\
$20 / 10 / 2010$ & 2191 & 190 & 94 & 350 & 8 & 330 & 620 & 522 & 10.2 \\
$20 / 11 / 2010$ & 2039 & 180 & 84 & 257 & 4 & 140 & 519 & 490 & 8 \\
$20 / 12 / 2010$ & 1960 & 210 & 114 & 250 & 6.7 & 115 & 518 & 639 & 1.8 \\
$20 / 1 / 2011$ & 1902 & 245 & 132 & 290 & 9 & 124 & 680 & 695 & 1.2 \\
$20 / 2 / 2011$ & 2012 & 170 & 78 & 246 & 2 & 132 & 518 & 470 & 8 \\
$20 / 3 / 2011$ & 2063 & 158 & 85 & 255 & 3 & 136 & 547 & 482 & 8 \\
$20 / 4 / 2011$ & 2097 & 190 & 87 & 310 & 6 & 155 & 624 & 520 & 4 \\
$20 / 5 / 2011$ & 2193 & 180 & 85 & 283 & 4 & 148 & 556 & 550 & 4 \\
\hline
\end{tabular}

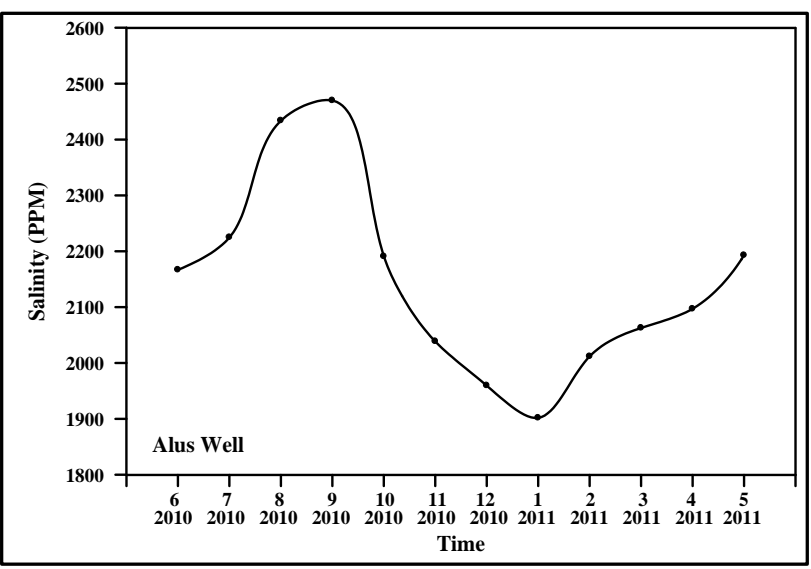

Figure 6. Groundwater salinity variation within time in well (A- Alus)

\section{Groundwater Origin and Quality:}

Sulin classification was used to identify water origin and the quality of groundwater in the area. Table (4) shows fifteen water types as Sulin could indicate (19). Figure 7 shows the water origins and types of groundwater samples according to Sulin classification, where marine origin and $\mathrm{MgCl}_{2}$ water types were recorded for forty three samples while only six samples were of continental origin and $\mathrm{Na}_{2} \mathrm{SO}_{4}$ water types. The aquifer in the basin represented by Tayarat, Umm Er-Radhuma, Dammam (subsurface), Anah and Euphrates as shown in Fig. 4 sections $\mathrm{A}, \mathrm{B}$ and $\mathrm{C}$, are marine depositional environment which mean that groundwater origin is marine water diluted with fresh rainwater infiltrated within fractures and joints extended in the area. 
Table 4. Sulin classification of water types (19)

\begin{tabular}{|c|c|c|c|c|c|}
\hline No. & Cations & Anions & No. & Cations & Anions \\
\hline 1 & Ca-Mg-Sodium & $\mathrm{HCO}_{3}-\mathrm{SO}_{4}-\mathrm{Chloride}$ & 9 & Ca-Magnesium & $\mathrm{HCO}_{3}$-Sulphate \\
\hline 2 & Mg-Sodium & $\mathrm{SO}_{4}-$ Chloride & 10 & Magnesium & Sulphate \\
\hline 3 & Mg-Ca-Sodium & $\mathrm{SO}_{4}-\mathrm{HCO}_{3}$ & 11 & Mg-Na-Calcium & $\mathrm{SO}_{4}-\mathrm{Cl}$-Bicarbonate \\
\hline 4 & Ca-Sodium & $\mathrm{HCO}_{3}$-Chloride & 12 & Na-Calcium & Cl-Bicarbonate \\
\hline 5 & Sodium & Chloride & 13 & $\mathrm{Na}-\mathrm{Mg}$-Calcium & $\mathrm{Cl}-\mathrm{SO}_{4}$-Bicarbonate \\
\hline 6 & Ca-Na-Magnesium & $\mathrm{HCO}_{3}-\mathrm{Cl}$-Sulphate & 14 & Mg-Calcium & $\mathrm{SO}_{4}$-Bicarbonate \\
\hline 7 & Na-Magnesium & Cl-Sulphate & 15 & Calcium & Bicarbonate \\
\hline 8 & Na-Ca-Magnesium & $\mathrm{Cl}-\mathrm{HCO}_{3}$-Sulphate & & & \\
\hline
\end{tabular}

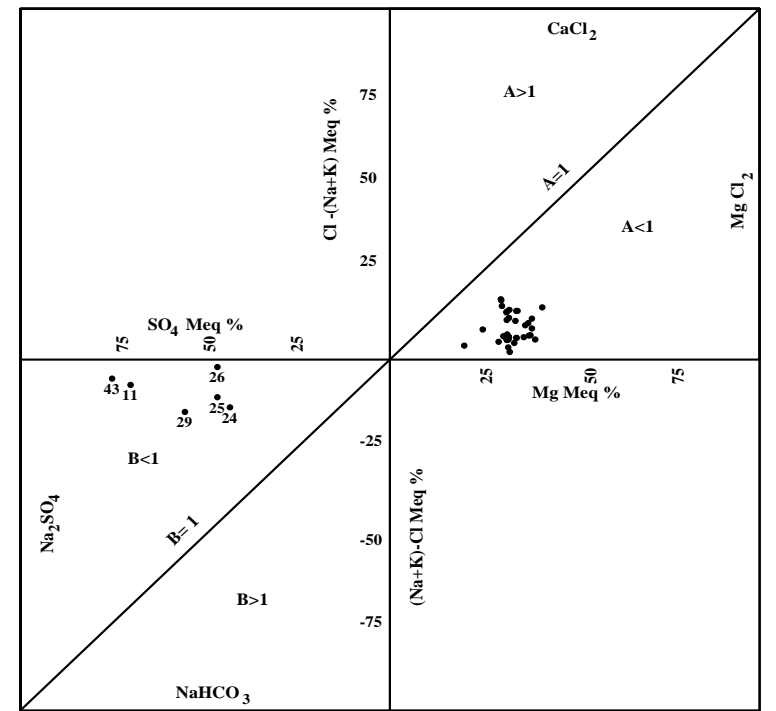

Figure 7. Origins and types of groundwater samples in study area.

\section{Groundwater Utilization:}

Depending on Table 5, groundwater utilization indicated that it can't be used for drinking purposes, while only three groundwater wells can be used for agricultural and thirty three groundwater used for animal purposes due to it high salinity. However, the nature of the soil in the area and the depth of the groundwater qualified water for agricultural uses in significant and wide range due to quaternary deposits which consisted of medium grained, well rounded pebbles, gypiferous soil, sand, silt and clay with high percentage of sand which holds only (20\%) of the irrigation water and it is irrigated daily to maintain the nutrients needed by the cultivated plants, which bears the highly concentrations of saline water, while decreasing elevations helps in accelerating the drainage process.

Table 5. Groundwater Utilizations standards

\begin{tabular}{|c|c|c|c|c|c|c|c|c|c|c|c|c|c|}
\hline 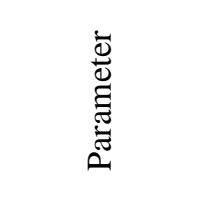 & $\frac{\pi}{2}$ & $\underset{\text { ن }}{ن}$ & 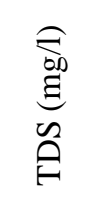 & 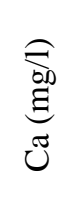 & 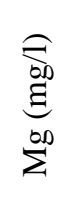 & 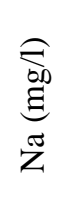 & 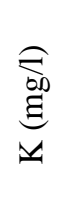 & 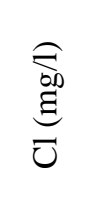 & 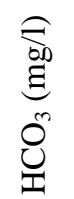 & $\begin{array}{l}\underset{\sigma 0}{60} \\
\text { है } \\
0^{+}\end{array}$ & 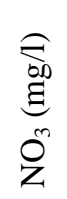 & 䍃 & 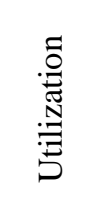 \\
\hline $\begin{array}{c}\text { Number of } \\
\text { samples }\end{array}$ & 49 & 49 & 49 & 49 & 49 & 49 & 49 & 49 & 49 & 49 & 49 & 49 & \multirow{5}{*}{ 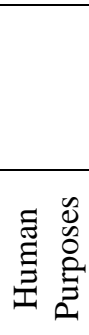 } \\
\hline Minimum & 7 & 1599 & 1048 & 125 & 74 & 160 & 2 & 300 & 25 & 518 & 0 & 2 & \\
\hline Maximum & 7.91 & 6800 & 4446 & 402 & 235 & 585 & 75 & 1180 & 483 & 1792 & 15 & 7.1 & \\
\hline $\begin{array}{c}\text { WHO (2011) } \\
(20)\end{array}$ & $6.5-8.5$ & - & 1000 & 75 & 125 & 200 & 12 & 250 & 200 & 250 & 50 & - & \\
\hline IQS (21) & $6.5-8.5$ & - & 1000 & 50 & 50 & 200 & 12 & 250 & 200 & 250 & 50 & - & \\
\hline $\begin{array}{c}\text { Standard } \\
\text { FAO/1989 } \\
(22,23)\end{array}$ & - & - & 2000 & 40 & 5 & 20 & - & 30 & 10 & 20 & - & 15 & 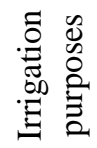 \\
\hline $\begin{array}{c}\text { Standard } \\
\text { FAO/1989 } \\
\text { Poultry }+ \\
\text { Livestock } \\
(22,23)\end{array}$ & - & 5000 & - & - & 250 & - & - & - & - & - & 100 & - & 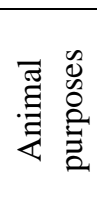 \\
\hline
\end{tabular}

\section{Conclusions:}

1- Values of $\mathrm{pH},(\mathrm{EC})$ and total dissolved solids (TDS) of groundwater's in northeast part of Anbar governorate were ranged from (7) to (7.9) and (1599) to (6800) $\mu \mathrm{mhos} / \mathrm{cm},(1048)$ to (4446) $\mathrm{mg} / \mathrm{l}$ respectively. Brackish to saline groundwater was detected in the study area where (TDS > $1000 \mathrm{mg} / \mathrm{l}$ ) 
2- The variation of (EC) and (TDS) concentrations was caused by the nature of geological waterbearing sequence and their groundwater origin, where groundwater within Tayarat, Umm ErRadhuma, Dammam and Anah had marine origins of highly concentrated ions, while the Euphrates and Fatha aquifer are also a marine origin, but are diluted with fresh rainwater infiltrated within fractures and joints extended in the area to decrease their concentrations.

3- The map of groundwater salinity distribution within area showed that salinity increased towards east and north east part of the basin to reflect a regular increasing in salinity concentrations due to groundwater flow direction within aquifer of carbonate formations.

4- Groundwater origins and types in the area were marine origin and $\mathrm{MgCl}_{2}$ water types, while only six samples were continental origin and $\mathrm{Na}_{2} \mathrm{SO}_{4}$ water types according to Sulin classification, where salinity increased due to increasing of ionic exchange ratios resulting from dissolution, where water-bearing layers consists of limestone and dolometic limestone of Euphrates, Anah and Fatha formations are the main aquifer in this area.

\section{Conflicts of Interest: None.}

\section{References:}

1. Abdul R S, Musthafa A. Geological structure that have control on groundwater occurrence of Chamarajanagar Taluk Chamarajanagar district southern Karnataka. IJG. 2015; 1: 1-9

2. Scanlon B, Keese K, Flint A, Flint L, Gaye C, Edmunds W, et al. Global synthesis of groundwater recharge in semiarid and arid regions.HP.2006; 20:3335- 3370.

3. Thilagavathi R, Chidambaram S, Thivya C, Prasanna M V, Pethaperumal S, Tirumalesh K A Study on the Behaviour of Total Carbon and Dissolved Organic Carbon in Groundwater's of Pondicherry Region, India. IJESE. 2014; 7: 1537-1550.

4. Harter T. Basic Concepts of Groundwater Hydrology, ANR Publication 8083, FWQP Reference Sheet 11.1, University of California. USA; 2015.

5. Ramesh D, Fritz F. Water Balance to Recharge Calculation: Implications for Watershed Management Using Systems Dynamics Approach.JH. 2016; 3 (13):1- 19.

6. Al-Sudani H I Z, Jawad, S B, Naom FH Bashoo DY, Ali BM. Hydrogeology of Aquifers in the Western Desert - West and South of Euphrates River. National Program of optimum use of water resources in Euphrates Basin. Axis IV, Ministry of Irrigation. Baghdad. Iraq. 2001; 100 p.
7. Jawad SB, Ridha SA. Assessment of groundwater resources in Iraq and management of their use. General Commission of Water Resources Management. Ministry of Water Resources. Baghdad Iraq. 2008; 19 p.

8. Jawad SB, Abdulrazaq MI, Ahmed AM. Transboundary aquifers between Iraq and neighboring countries. General Commission of Water Resources Management. Ministry of Water Resources. Baghdad Iraq.2008;52.

9. Al-Sudani HIZ. Hydrogeological study of Khan AlBaghdadi area in Anbar Governorate - West of Iraq. DJPS2017; 13 (2): 192-207.

10. Al-Sudani HIZ. Influence of Structural Factors on Groundwater System - West of Iraq. BJS (A). 2018; 36 (1):1-15.

11. Sissakian VK Salih SM. The Geology of the Ramadi Quadrangle Sheet NI-38-9 (GM 13) Scale 1:250000. (GEOSURV). Baghdad Iraq. 1994;30.

12. Hussein DA. Geological and Hydrogeological information of Groundwater wells in Anbar Governorate. General Commission of Groundwater. Ministry of Water Resources. Baghdad Iraq; 2011.

13. APHA. Standard Methods for the Examination of Water and Wastewater. $21^{\text {st }}$ Edition, American Public Health Association, Washington DC; 2005.

14. Al-Sudani HIZ. Groundwater Investigation in Iraqi Marshland Area. DJ PS. 2017b; 13 (3): 12-29

15. Selvakumar S, Ramkumar K, Chandrasekar N, Magesh NS, Kaliraj S. Groundwater Quality and Its Suitability for Drinking and Irrigational Use in the Southern Tiruchirappalli District, Tamil Nadu, India AWS, 2014;1-10.

16. Robinson M, Ward R. Hydrology principles and processes. IWA. 2017; 400p.

17. Poornima KB, Kumar SKP, Varadarajan N, Purandara BK. Estimation of Root Zone Salinity Using SALTMOD-A Case Study. IJAR, 2014; 2: 858-870.

18- Al-Sudani HIZ. Calculating of Groundwater Recharge using Meteorological Water Balance and Water level Fluctuation in Khan Al-Baghdadi Area. IJS. 2018; 59 (1B): 349-359.

19. Nagaraju A, Muralidhar P, Sreedhar Y. Hydrogeochemistry and Groundwater Quality Assessment of Rapur Area, Andhra Pradesh, South India GEP 2016; 4: 88-99

20. WHO. Guidelines for drinking water quality. World Health Organization, fourth edition, Geneva, 5(541).2011

21.IQS:Drinking-WaterStandard,417.Central Organization for Quality Control and Standardization, Council of Ministers, Republic of Iraq. 2001.

22. Ayers RS, Westcot DW. Water Quality for Agriculture, Irrigation and Drainage Paper 29, rev. 1, Food and Agriculture Organization of the United Nations, Rome. Italy. 1994; 174.

23. Rao NS, Vidyasagar G, Rao PS, Bhanumurthy P. Chemistry and Quality of Groundwater in a Coastal Region of Andhra Pradesh India AWS, 2014: 1-10. 
هيدروكيميائية المياه الجوفية في الجزء الثمالي الشرقي من محافظة الانبار ـ غرب العراق

حسين العيبي زامل السوداني

قسم تكنولوجيا النفط، الجامعة التكنولوجية، بغداد، العراق.

تم تقييم نوعية المياه الجوفية في منطقة خان البغدادي التي تقع إلى الثمال الثرقي من محافظة الأنبار في غرب العراق التئية لتحديد

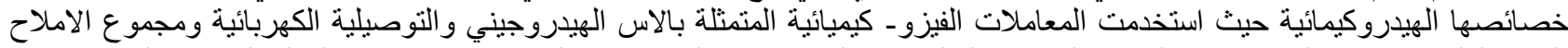

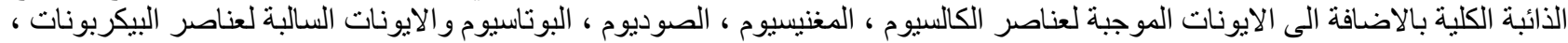

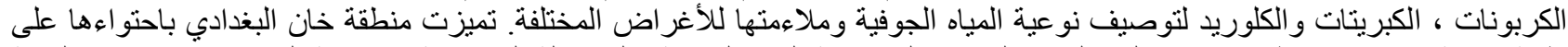

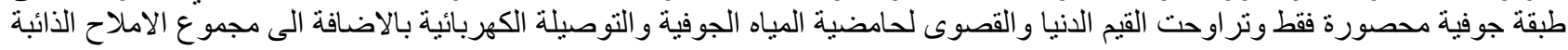

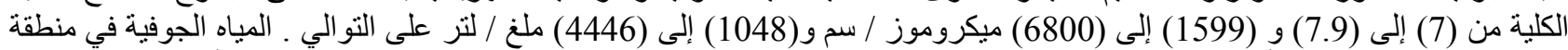

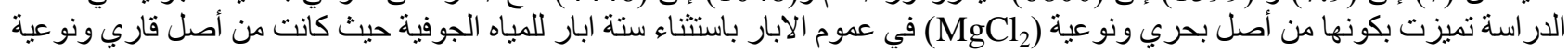

. $\left(\mathrm{Na}_{2} \mathrm{SO}_{4}\right)$

الكلمات المفتاحية: هيدروكيميائية واستخدامات المياه الجوفية، توزيع وتغاير الملوحة، غرب العراق. 